\title{
Collaborative Value-Chain Design of Reward-Based, Crowd-Funding Platforms in the Indonesian Music Industry
}

\author{
Octadila Laily Anggraeni, Elvia R. Shauki*
}

\author{
Master of Accounting, Universitas Indonesia, Depok, Indonesia \\ *Corresponding author. Email: elvia.shauki@icloud.com
}

\begin{abstract}
Rapid advancement in technology has brought about many life changes. Technology simplifies the way people do many things, and it saves time, energy, and cost. The financial sector, for instance, is characterized by the growth of financial technology. One example of this is crowd funding. Creative industries such as music, film, and games are quite high sectors use crowd funding. This research covers crowd-funding platform collaborations with the music industry in Indonesia. In this process, to maximize the collection of funds, the musicians needs to do a value chain analysis and divine its competitive advantages. Such collaboration opens new business deals and changes the value chain. This study analyzes value chain designs and the collaboration between reward-based, crowd-funding platforms and the music industry in Indonesia. The research, which is based on value network theory and uses a qualitative approach and many case studies, was conducted by gathering information from participants involved in crowd funding in the music industry. The results of the study show that collaboration changes the design of the value chain. Crowd funding has changed the method of production in the Indonesian music industry, which involves funding, product development, sales, and distribution until the product reaches customers' hands. Other forms of crowd-funding in other creative industries require further investigation. This research aims to help practitioners understanding how reward-based crowd funding is changing the music industry in Indonesia.
\end{abstract}

Keywords: value chain, reward-based crowd funding, music industry

\section{INTRODUCTION}

Industry 4.0 is the trend towards automation and data exchange in manufacturing technologies. Industry 4.0 has brought many conveniences to everyday life. Almost all activities are carried out with the help of the internet (Ernst \& Young, 2018; Kagermann, H., Lukas, W., \& Wahlster, 2011; Marr, 2016). Ernst \& Young noted that the industry 4.0 was disruptive or destructive. In the era of the industrial revolution 4.0, almost everyone was forced to work online rather than online. Some human interactions and daily activities have been replaced with the internet, such as transportation, finance, and shopping for necessities. The internet accomplishes these tasks quickly and easily.

In the finance sector, financial technology companies are growing rapidly. As of February 1, 2019, 99 financial technology platforms were registered with OJK (Otoritas Jasa Keuangan, 2019). While the types of financial technology companies are diverse, Bank Indonesia broadly categorizes financial technology into four major groups based on their activities: payment systems, market aggregators, investment and risk management, and loans, 
financing, and capital provision (Bank Indonesia, 2017). Payment systems are gateways that help people make payments online. Market aggregators support financial markets by helping users compare information about financial products and choosing the one that suits their needs. Investment and risk management helps arrange digital financial planning. Loans, financing and the provision of capital incorporate peer-to-peer lending and crowd funding. Peer-to-peer lending accesses channel investors' funds with loans to micro-entrepreneurs (MSMEs), who find it difficult to apply to banks for loans. Crowd funding raises funds from the public for investment or social purposes.
Paschen (2017) divides crowd-funding into three groups: donations, loans, and capital. His crowd-funding typology is illustrated in Table I below. Badan Ekonomi Kreatif $(2016,2017)$ mention that crowd-funding can be a credible funding model for creative industries, which utilize crowd-funding models. A report submitted by Kickstarter shows that projects in music, film, and games have been successfully funded with the most dollars. The total funds collected for the three industries equal $45 \%$ of Kickstarter's total registered projects (Kickstarter, 2019). In Indonesia, Kolase.com is one crowd-funding platform that focuses on creative industries, especially music. We note that the scope of this research is limited to crowdfunding platform collaborations and the music industry.

Table1. Crowd-funding Typology (Paschen, 2017)

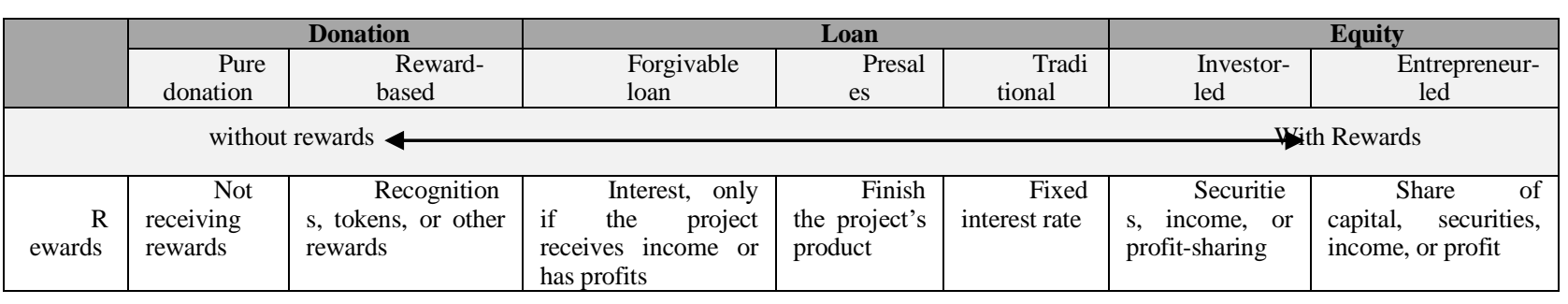

Rapid technological developments have changed customers' tastes and made competition more uncertain. On the other hand, a niche market exists because customers seek customization to satisfy their individual preferences and tastes (Russ, Kuilboer, \& Ashrafi, 2014). In this challenging environment, companies must have a competitive advantage to survive. Competitive advantages cannot be understood by looking at companies as a whole. Porter (1995) introduced value chains as a tool to help companies better recognize their competitive advantages and to determine strategies.

I In the collaboration between crowd-funding platforms and the music industry, to maximize funds collection, value chain analysis and competitive advantages need to be assessed. Nucciarelli et al. (2017) explained that the consequences of a collaboration is a new business model that changes the value chain and impacts the relationship between developers and other industry stakeholders. However, the collaborative value chain between crowd-funding platforms and the music industry is different from their respective value chains, and this is the subject of our research. Collaborative value chain design can be used by musicians to maximize the value of their creations.

Previous research conducted by Hadida \& Paris (2014) about managerial changes in the music industry shows that the digital music industry strengthened value chains better than the traditional music industry. The cognitive framework of a value chain can influence how investors interpret the digital music industry. Their research did not include collaborative elements between technology and the music industry.

Gamble, Brennan, \& McAdam (2017) and Pastonesi (2013) conducted an exploratory study about how rewardbased crowd funding affected the development of the music industry. Crowd funding contributes to marketing and brings musicians closer to their listeners. It also provides a way for musicians to obtain funding for production and to obtain greater control when working with record companies. The above two studies, though, did not include the value chain element. Research conducted by Nucciarelli et al. (2017) combined elements from previous research to assess how reward-based crowd funding created value in the digital game industry. This study replicates Nuciarelli's research, with different objects, locations, and research dates.

This research, which is based on value network theory, uses a qualitative approach and multiple case studies. This helps us observe similarities and differences between the cases studied (Stake, 2006). This research observes the value-chain transformation created by a collaboration between a reward-based, crowd-funding platform and the 
music industry. We expect that it will help practitioners understand the competitive advantages of this collaboration.

The research is organized as follows. Section 1 discusses background and research problems, Section 2 provides a literature review of crowd funding and the theory underlying the research, Section 3 discusses the design and research methods in detail. Section 4 offers the results of the music industry analysis and the value chain transformation created by the collaboration between the music industry and reward-based crowd funding, and Section 5 provides conclusions and suggestions for future research.

\section{LITERATURE REVIEW}

\subsection{Value Networks}

Value network theory was introduced by Stabell \& Fjeldstad (1998), who explained that the value creation process allows exchanges in networks with scales and compositions of in accordance with members' needs. Values are created when value networks facilitate interactions.

\subsection{The Value Chain}

First introduced by Porter (1995), a value chain was defined as a series of processes carried out by companies to identify key activities and to support activities related to value creation. The value chain provides an ideal framework for examining how the value proposition works, its cost structure, and a company's business model.

The value proposition explains why customers choose a product. Value creation can be maximized through value chain analysis (Thompson, Strickland III, Gamble, \& Peteraf, 2017). The higher the value proposition of a product, the higher a customer's willingness to purchase it.

In a value chain, a company's activities are divided into two groups, main activities and supporting activities. The relationship between the two is shown in Figure I.

While the activities mentioned above create the value chain, they vary according to each business model's specifics. Through a value chain, companies can analyze their cost structure and the value creation process and conduct evaluations to effectively maximize a competitive advantage.

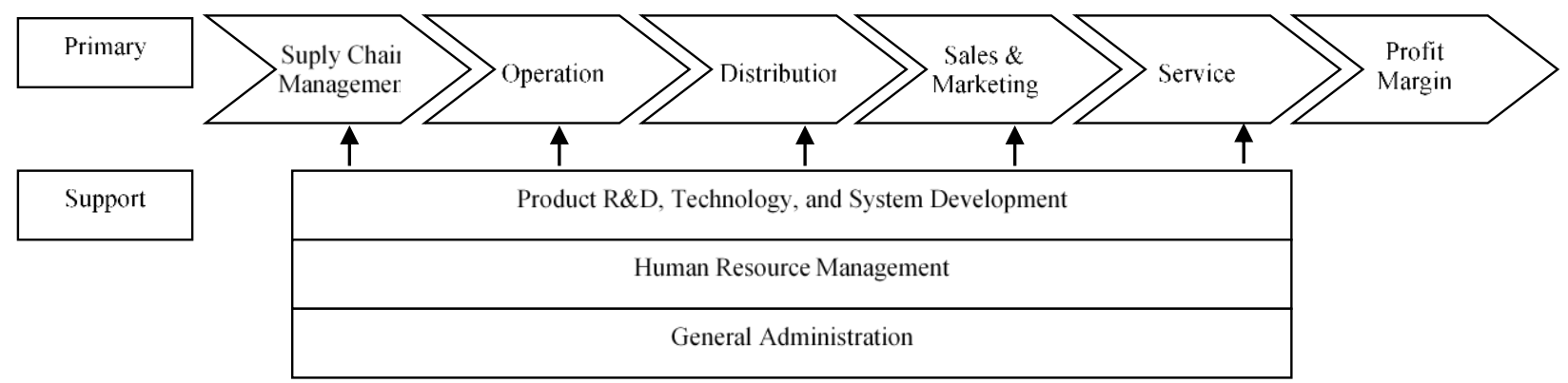

Figure I. Value chain (Thompson et al., 2017)

Hadida \& Paris (2014) shows that the music industry's value chain design changed when the business transitioned from traditional to digital. A value chain's cognitive framework can influence investors' interpretation of the digital music industry. Hadida and Paris's research did not include collaborative elements between technology and the music industry. This study aims to fill this research gap.

\subsection{Financial Technology}

Bank Indonesia (2017) defines financial technology as the use of technology in a financial system to provide services, products, or new business models. Since this phenomenon is relatively new in Indonesia, Bank Indonesia only regulated it beginning in 2017. These regulations are divided into four groups: payment gateways, market support, investment and risk management, and crowd funding and peer-to-peer lending. The financial technology industry is growing rapidly. As of January, 2019, 192 financial technology companies operated in Indonesia, consisting of 161 start-up companies, 22 financial institutions, and nine associate partners (Fintech Indonesia, 2019).

\subsection{Crowd Funding}

One form of financial technology is crowd funding. In their report, Kirby \& Worner (2014) explain that crowd funding is a sum of funds collected by large groups of individuals or groups to fund business or personal projects through web-based platforms. Kirby \& Worner (2014) 
then explained that there are four crowd-funding categories: donations, reward-based, loans, and capital. Conversely, Bank Indonesia (2017) divided crowd funding into three major groups: donations, loans, and capital. Paschen also categorized crowd funding based on rewards earned. The crowd-funding typology proposed by Paschen (2017) is explained in Table 1.

\subsection{Reward-Based Crowd Funding}

Paschen (2017) divides crowd-funding donations into two groups: pure donations and reward-based. When doing reward-based crowd funding, organizations or groups that need funds offer a return to the funds' owner in the form of goods or services from the project or work. Reward-based crowd funding is very popular in creative industries, and the rewards to fund owners are the work produced. One reward-based, crowd-funding platform in Indonesia is Kolase.com. Until February, 2019, Kolase.com had successfully funded 54 projects and collected Rp 1.1 billion (Kolase.com, 2019).

Research conducted by Gamble et al. (2017) and Pastonesi (2013) showed that crowd funding is able to bring musicians closer to their listeners. It also can help musicians obtain funding for production activities and provide greater control when collaborating with record companies. Neither Gamble, Brennan, and McAdam and Pastonesi incorporated value chain analysis.

Subsequent research conducted by Nucciarelli et al. (2017) integrated value-chain logic and collaborations between crowd-funding platforms and the gaming industry. Nucciarelli et al. (2017) found that crowd funding not only raises funds but also brings together capital, technology, and market knowledge. Their findings also explain the effects of crowd-funding on the gaming industry.

This research will investigate collaborations between reward-based, crowd-funding platforms and the music industry in Indonesia and fill gaps in the research of Gamble et al. (2017) and Pastonesi (2013). To obtain an overview of collaboration in the design of value chains, this study also will integrate value chain logic.

\subsection{Research Framework}

This research was formulated using a framework shown in Figure II. The study aims to produce a collaborative value chain design between reward-based, crowd-funding platforms and the music industry to help understand the structure of this chain. The research is based on value network theory, with the music industry and all parties involved in crowd-funding platforms included as members of the network. Numerous case studies were used to find funding cases' similarities and differences regarding crowd-funding platforms, as well as the effects of collaboration.

\section{RESEARCH METHOD}

This research was conducted to analyze new valuechain designs created from collaborations between reward-based, crowd-funding platforms and the music industry in Indonesia. In this chapter, we discuss the strategy, research approach, data collection, analytic methods, and units of analysis.

VALUE NETWORK THEORY (Stabell \& Fjeldstad, 1998)

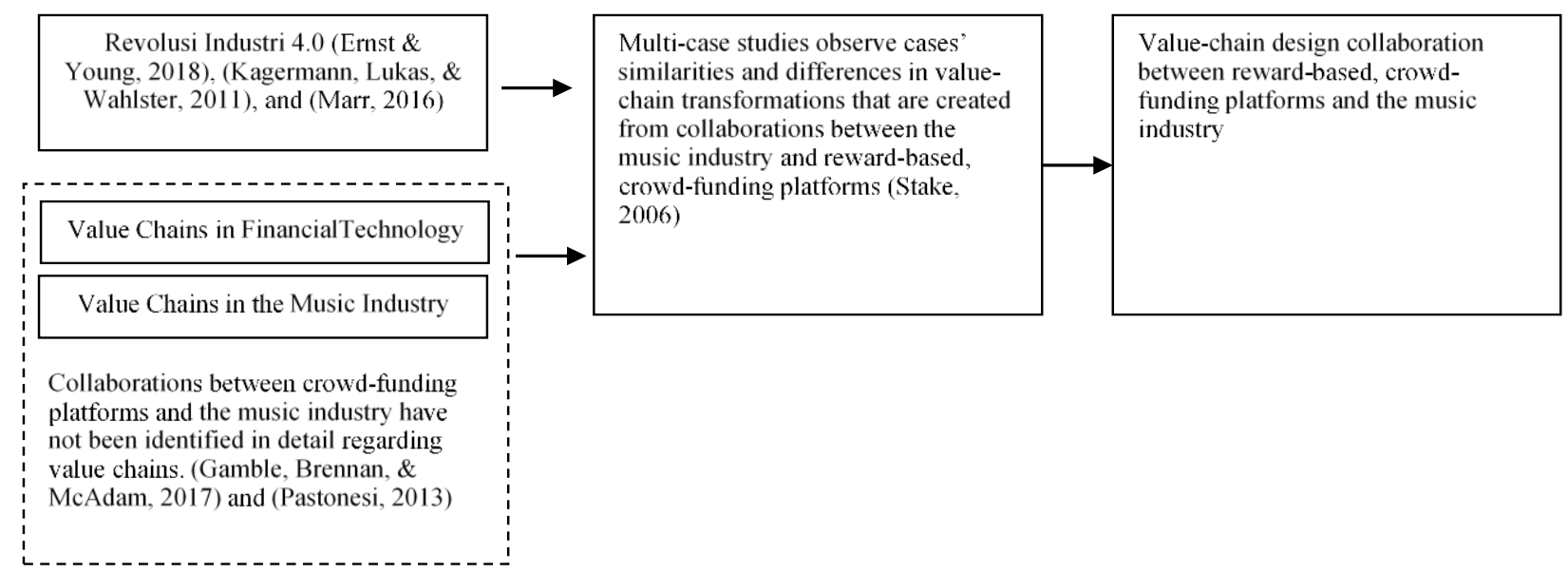

Figure 2. Research Framework 


\subsection{Research Strategy}

Yin (2003) defines case studies as research methods that explain how a phenomenon occurs and Stake (2006) defines them as research methods used to determine the unique characteristics of each case. Stake also explained that it is necessary to extract information and in-depth analysis from case studies. This study uses a case-study research strategy because it aims to fully understand how collaborative crowdfunding platforms interact with the music industry.

Stake (2006) explains that two types of case studies exist: single- and multi-case studies. In the latter, numerous cases are observed, using the same procedure and analysis. Using multi-case studies, this research will investigate the interaction between several collaborative music projects and reward-based, crowd-funding platforms regarding value creation.

\subsection{Research Approach}

This study uses a qualitative approach. Yvonna and Egon Guba (1985) in Stake (2006) show that qualitative research is based on social phenomena, social dilemmas, and the situational nature of cases. A qualitative approach was developed to study real case experiences.

This study uses written, qualitative data, such as interview notes, transcripts, and open statements on the internet. Qualitative data analysis is intended to make valid conclusions from the data collected (Sekaran, U., \& Bougie, 2016). This study used only qualitative data obtained from interviews about reward-based, crowdfunding platforms and from music industry collaborators who have crowd-funding platforms.

\subsection{Data Collection}

\subsubsection{Data Sources}

The data used in this study are primary data collected by researchers directly for specific research purposes (Sekaran, U., \& Bougie, 2016). Primary data was obtained from speakers dealing with reward-based, crowd-funding platforms and from music industry collaborators with crowd-funding platforms.

\subsubsection{Research Instruments}

We use four main methods to obtain primary data: interviews, observations, questionnaires, and experiments (Sekaran, U., \& Bougie, 2016). The research instruments are semi-structured interviews and content analyses. Semi-structured interviews are used to gain an in-depth understanding of the phenomena that occur, along with a guide to the list of questions, prepared before the interviews that answer research problems. The semi-structured interview model makes the interview more flexible, leading to a better understand of the information explored. To understand the overall value chain, semi-structured interview questions were designed to gather data about the overall crowd-funding process, from production, marketing, and distribution to customers, both from crowd-funding and musicians' platforms. The interview results are then grouped according to the associated value chain stages, which define the collaborative value chain's design.

In addition to interviews, content analysis is used. Kolbe \& Burnett (1991) in Sekaran, U., \& Bougie (2016) define content analysis as an observational research method that systematically evaluates and records the content of all forms of communication. The results of the interviews collected in this study will be analyzed using content analysis.

\subsection{Data Analysis}

The data analysis method used in this study is content analysis. Content analysis can be used to analyze newspapers, websites, advertisements, interview records, and other forms of information. It analyzes textual information and systematically identify its properties, such as the existence of certain words, concepts, characters, themes, or sentences (Sekaran, U., \& Bougie, 2016).

Data from the interviews obtained in this study will be analyzed by groups according to the type and context of the information obtained. Initially, two large groups of data will be created, the results of interviews from the crowd-funding platform based on rewards and the results of interviews from each selected music project. Furthermore, the results of selected music project interviews will be grouped again according to the nature and type of project. The study makes use of five music album-making projects.

\subsection{Unit of Analysis}

The unit of analysis in this study is multi-unit. The object of the research is a reward-based, crowd-funding platform and music projects that collaborate with crowd-funding platforms. The selected reward-based, crowd-funding platform is Kolase.com, an online joint venture formed by PT Kirai Adiwarna Nusantara (KAWAN). Kolase.com is currently the only reward- 
based, crowd-funding platform that specifically handles music collaboration projects. Kolase.com connects musicians with their fans and also funds owners who want to finance musicians' projects, including albums, tours, and music concerts. Since its launch on February 1, 2018, Kolase.com has completed 54 collaborations of different types and collected Rp 1.1 billion at the end of February, 2019. Kolase.com (2019) has 20,267 members, and every customer who donates to an art project on Kolase.com must join the website. The other unit of analysis is music projects resulting from collaborations between Kolase.com and musicians. These projects are albums, the most representative and complex form in the industry. We assess all aspects of album-making, from production to music to customers. Since its launch, there have been 11 album-making projects, and five of them have been completed. This research will select five completed, collaborative projects, which will be analyzed further to understand collaborative value-chain results formed from the reward-based, crowd-funding platform (Kolase.com) and the music projects. In the discussion, either musicians or others organize campaigns on crowd-funding platforms.

\section{RESULTS AND DISCUSSION}

This section will analyze the research results, including a general description of research respondents, and the process of obtaining data. The discussion will focus on research objectives, primarily how a value chain's design affects crowd-funding platforms, value chain design in the music industry, and the generation of collaborative value chain design in the crowdfunding process. Interviews in this study were conducted with members of the crowd-funding platform Kolase.com and participants in album-making projects. As of March 1, 2019, five album-making projects had been successfully funded, and all were targeted by respondents.

Because of limited access and time, research interviews were conducted only with crowd-funding platform managers and members of three targeted projects. The overall response rate was $60 \%$, and access to interviews is available on Kolase.com's crowd-funding platforms.

\subsection{Research Findings}

\subsubsection{Value Chains in Reward-Based, Crowd- Funding Platforms}

Based on information gathered during interviews with members of crowd-funding platforms, Kolase.com is a platform that raises funds from customers for musicians. Crowd-funding platforms largely work the same way as other internet-based platforms, such as social media sites, where users can create projects directly on the Kolase.com webpage. In practice, though, to appeal to prospective customers, users still need assistance to compile information published on Kolase.com. Furthermore, although musicians control the entire creative process, some request advice about merchandising and funding packages that appeal to customers who follow crowd funding.

Kolase.com helps participants promote their work through social media, press releases, and promotional material in the form of photos and videos. For distribution, Kolase.com collaborates with freight forwarders who are integrated with the platform. This eases distribution to customers and minimizes the risk of shipping errors. After completion of a campaign, Kolase.com informs the user about who joined the crowd-funding project. This database contains customers' gender, age, and area of origin.

Kolase.com also provides a polling feature that campaigns can use for research before embarking on a project. Information that can be polled includes the location of a concert, guest stars of artistic events, choice of album covers, and the price of manufactured merchandise. This feature greatly assists campaigns obtain information about their target markets.

\subsubsection{Value Chains in the Music Industry}

As shown in Table II, information about value chains in the music industry was collected during interviews with music industry participants. The interviews revealed that crowd funding is not limited to fundraising; it also influences other components of the value chain and changes producing patterns. At least five primary activities in the value chain change. First, new funding is obtained from customers who follow crowd funding. This was confirmed in the Respondent $\# 1$, where all production costs were obtained from crowd funding. Second, the polling of crowd-funding platforms is used by musicians to research prospective customers' tastes before making a work. Although known by musicians, polling sometimes is not utilized 
because most musicians already have a concept in mind.

\begin{tabular}{|c|c|c|c|}
\hline Value Chain & Respondent \#1 & Respondent \#2 & Respondent \#3 \\
\hline Funding & $\begin{array}{l}100 \% \text { from crowd } \\
\text { funding. }\end{array}$ & $\begin{array}{l}\text { Album production costs are } \\
\text { borne by the musicians. } \\
\text { Physical production costs of } \\
\text { albums are funded by crowd } \\
\text { funding on Kolase.com. }\end{array}$ & $\begin{array}{l}\text { Album production costs are } \\
\text { borne by the musicians. } \\
\text { Physical production costs of } \\
\text { albums are funded by crowd } \\
\text { funding on Kolase.com. }\end{array}$ \\
\hline $\begin{array}{l}\text { Development \& } \\
\text { Production }\end{array}$ & $\begin{array}{l}\text { The entire creative } \\
\text { process of the } \\
\text { album and the } \\
\text { merchandising is } \\
\text { done by the } \\
\text { musicians. }\end{array}$ & $\begin{array}{l}\text { The entire creative process of } \\
\text { the album and the } \\
\text { merchandising is done by the } \\
\text { musicians. }\end{array}$ & $\begin{array}{l}\text { The entire creative process of } \\
\text { the album and the } \\
\text { merchandising is done by the } \\
\text { musicians. }\end{array}$ \\
\hline $\begin{array}{l}\text { Sales \& } \\
\text { Marketing }\end{array}$ & $\begin{array}{l}\text { Kolase.com } \\
\text { provides } \\
\text { promotional } \\
\text { material in the form } \\
\text { of photos and } \\
\text { videos. }\end{array}$ & $\begin{array}{l}\text { Kolase.com provides } \\
\text { promotional material in the } \\
\text { form of photos, videos and press } \\
\text { releases and sends blast emails } \\
\text { related to album projects to all } \\
\text { its members. }\end{array}$ & $\begin{array}{l}\text { Kolase.com provides } \\
\text { promotional material in the } \\
\text { form of photos, videos and press } \\
\text { releases and sends blast emails } \\
\text { related to album projects to all } \\
\text { its members. }\end{array}$ \\
\hline Distribution & $\begin{array}{l}\text { The distribution } \\
\text { process is carried } \\
\text { out by the } \\
\text { musicians. }\end{array}$ & $\begin{array}{l}\text { The distribution process is } \\
\text { carried out by JNE, which is } \\
\text { integrated with Kolase.com. }\end{array}$ & $\begin{array}{l}\text { The distribution process is } \\
\text { carried out by JNE, which is } \\
\text { integrated with Kolase.com. }\end{array}$ \\
\hline Market & $\begin{array}{l}\text { DVDs and } \\
\text { merchandise are } \\
\text { tailored to } \\
\text { customer profiles. } \\
\text { After crowd } \\
\text { funding is } \\
\text { complete, } \\
\text { Kolase.com hands } \\
\text { over the customer } \\
\text { database. }\end{array}$ & $\begin{array}{l}\text { DVDs and merchandise } \\
\text { produced are limited only to } \\
\text { customers who follow crowd } \\
\text { funding. } \\
\text { After crowd funding is } \\
\text { complete, Kolase.com submits a } \\
\text { customer database that can be } \\
\text { used to plan the next work. }\end{array}$ & $\begin{array}{l}\text { DVDs produced are limited to } \\
\text { customers who follow crowd } \\
\text { funding. } \\
\text { Merchandise is customized for } \\
\text { each customer. } \\
\text { After crowd-funding is } \\
\text { complete, Kolase.com submits a } \\
\text { customer database that can be } \\
\text { used to plan the next work. }\end{array}$ \\
\hline
\end{tabular}

Third, in terms of sales and marketing, crowd-funding platforms help musicians prepare promotional materials for prospective customers. Promotional assistance from crowd-funding platforms, through e-mailed press releases to members and promotions through social and electronic media, extends products' market reach. Fourth, a crowdfunding distribution platform helps musicians send their work to customers, because the platform is integrated with a logistics system (for Respondents \#2 and \#3 but not for Respondent \#1). Fifth, after a project is completed, the crowd-funding platform sends musicians a database of customers who participated in the project. Information in the database includes customers' gender, age, region of domicile, and social media presence.

A Discussion about Collaborative Value-Chain Design in Reward-Based, Crowd-Funding Platforms in Indonesia's Music Industry
This paper studies collaborative value-chain designs in Indonesia's music industry crowd-funding platforms. The proposed framework design is illustrated in Figure III below.

This research uses value-chain logic to analyze value creation in the collaborative process between crowdfunding platforms and the music industry. The study's results show that crowd funding has changed the music industry. Notably, the process of creating value has undergone many alterations. In the main activity, shown in Figure II, all components of the value chain collaborate to create value in crowd-funding platforms and in the music industry. Musicians obtain new funding from crowd funding. Later, in the product development stage, they can take advantage of research facilities provided by crowdfunding platforms. When selling and distributing products to customers, integration between crowd-funding platforms and logistics companies is quite helpful. Musicians also obtain customer databases at the end of the 
project. Collaboration in the design of the value chain helps musicians analyze the competition and create value from this collaboration.

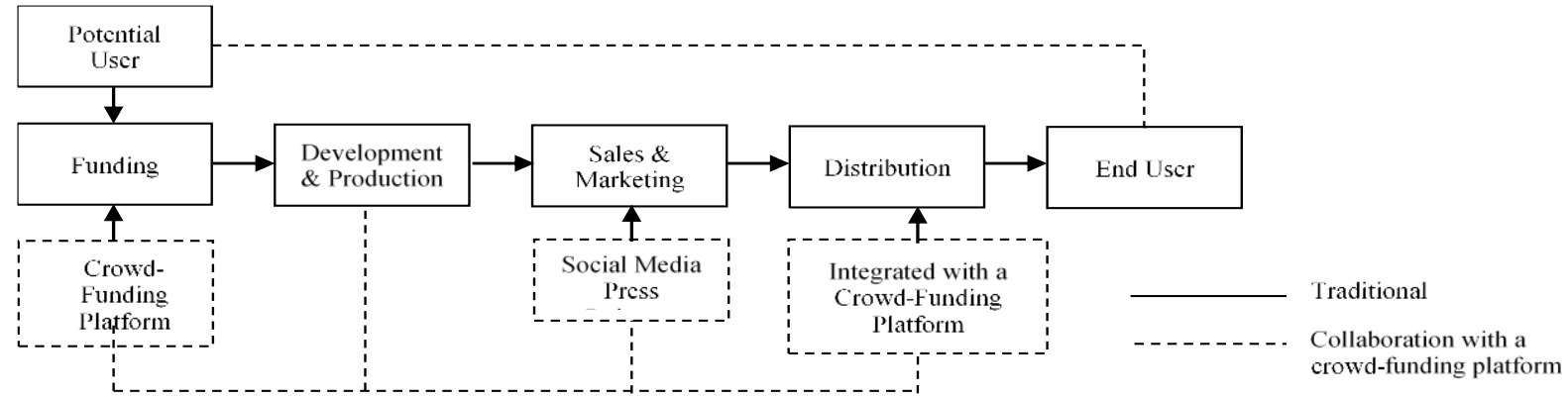

Figure 3. Collaborative Value-Chain Design

In terms of value network theory, the interaction of musicians and customers through crowd-funding projects creates value. Customers fund musicians through crowdfunding platforms, and musicians send products to customers based on data processed by crowd-funding platforms. All parties involved in the crowd-funding process are interdependent in the value-creation process.

\section{CONCLUSION AND IMPLICATIONS}

This section summarizes the results of the research, explains the limitations of the study, and provides suggestions for subsequent research. This research aims to understand value chain design that results from collaborations between crowd-funding platforms and the music industry in Indonesia. It was found that the collaboration process occurs in almost all the value chain's main activities. Crowd funding indirectly changed the Indonesian music industry's pattern of production by combining funding, product development, sales, and distribution, until the product reaches customers' hands. The role of crowd-funding platforms as a conduit between musicians and their customers creates value and is a form of value network application theory.

\section{RESEARCH LIMITATIONS}

Because of time constraints, this study's response rate was $60 \%$. This figure can be improved by extending the period of study. In addition, this study only analyzes album-making projects, despite the fact that the music industry incorporates other types of projects.

To obtain a broader and more varied picture of the collaboration between crowd-funding platforms and the music industry in Indonesia, further research can increase the number of respondents in the study and the types of projects analyzed. In addition, research can be carried out about how crowd funding affects entrepreneurial decisions in creative industries. This research also would help researchers understand the effects of social capital on crowd-funding project design

\section{REFERENCES}

[1] Badan Ekonomi Kreatif. (2016). Mengenal Crowdfunding. Retrieved February 28, 2019, from http://indonesiakreatif.bekraf.go.id/ikpro/financials/m engenal-crowdfunding/

[2] Badan Ekonomi Kreatif. (2017). Ekonomi Kreatif Outlook 2017: Era Ekonomi Kreatif harus menjadi tulang punggung ekonomi Indonesia. 82.

[3] Bank Indonesia. (2017). Peraturan Bank Indonesia Nomor 19/2/PBI/2017. (Tentang Transaksi Sertifikat Deposito di Pasar Uang). Retrieved from http://www.bi.go.id/id/peraturan/moneter/Documents /PBI_190217.pdf

[4] Ernst \& Young. (2018). Industry 4.9: engaging with disruption. Ahmedabad.

[5] Fintech Indonesia. (2019). Fintech Indonesia. Retrieved February 20, 2019, from https://fintech.id/

[6] Gamble, J. R., Brennan, M., \& McAdam, R. (2017). A rewarding experience? Exploring how crowdfunding is affecting music industry business models. Journal of Business Research, 70, 25-36. https://doi.org/10.1016/j.jbusres.2016.07.009

[7] Hadida, A. L., \& Paris, T. (2014). Technological Forecasting \& Social Change Managerial cognition and the value chain in the digital music industry. Technological Forecasting \& Social Change, 83, 8497. https://doi.org/10.1016/j.techfore.2013.04.005 
[8] Kagermann, H., Lukas, W., \& Wahlster, W. (2011). Industry 4.0: With the Internet of Things on the way to the 4th industrial revolution. In Vdi-Nachrichten.

[9] Kickstarter. (2019). Successfully Funded Projects. Retrieved February 10, 2019, from Kickstarter Web Page website: https://www.kickstarter.com/help/stats

[10] Kirby, E., \& Worner, S. (2014). Crowdfunding: An infant industry growing fast. IOSCO Research Department, 1-62. https://doi.org/10.1037/0893164x.19.2.208

[11] Kolase.com. (2019). Kolase.com. Retrieved February 20, 2019, from https://www.kolase.com/

[12] Marr, B. (2016). Why Everyone Must Get Ready For The 4th Industrial Revolution. Retrieved February 20, 2019, from Forbes website: https://www.forbes.com/sites/bernardmarr/2016/04/0 5/why-everyone-must-get-ready-for-4th-industrialrevolution/\#5af877b33f90

[13] Nucciarelli, A., Li, F., Fernandes, K. J., Goumagias, N., Cabras, I., Devlin, S., ... Cowling, P. (2017). From value chains to technological platforms: The effects of crowdfunding in the digital game industry. Journal of Business Research, 78, 341-352. https://doi.org/10.1016/j.jbusres.2016.12.030

[14] Otoritas Jasa Keuangan. (2019). Penyelenggara Fintech Terdaftar di OJK per 1 Februari 2019. Retrieved February 10, 2019, from Publikasi OJK website: https://www.ojk.go.id/id/berita-dankegiatan/publikasi/Pages/Penyelenggara-FintechTerdaftar-di-OJK-per-Februari-2019.aspx

[15] Paschen, J. (2017). Choose wisely: Crowdfunding through the stages of the startup life cycle. Business Horizons, 60(2), 179-188. https://doi.org/10.1016/j.bushor.2016.11.003
[16] Pastonesi, R. (2013). The impact of crowdfunding on musicians' business: Findings from Denmark, Norway, and Sweden. Retrieved from https://repositorio.ucp.pt/bitstream/10400.14/14071/1 /Master Thesis_Rocco Pastonesi.pdf

[17] Porter, M. (1995). Competitive Advantage: Creating and Sustaining Superior Performance. New York: Free Press.

[18] Russ, H., Kuilboer, J.-P., \& Ashrafi, N. (2014). Business Intelligence in the Music Industry Value Chain: Ensuring Sustainability in a Turbulent Business Environment. International Journal of Business Intelligence Researchgence Research, 5(1), 50-63. https://doi.org/10.4018/ijbir.2014010104

[19] Sekaran, U., \& Bougie, R. (2016). Research Methods for Business: A Skill-Building Approach (7th Editio). New Jersey: John Wiley \& Sons Ltd.

[20] Stabell, C. B., \& Fjeldstad, Ø. D. (1998). Configuring value for competitive advantage: on chains, shops, and networks. Strategic Management Journal, 19(5), 413-437. https://doi.org/10.1002/(sici)10970266(199805)19:5<413::aid-smj946>3.3.co;2-3

[21] Stake, R. E. (2006). Multiple Case Study Analysis THE GUILFORD PRESS New York London. Retrieved from www.guilford.com

[22] Thompson, A., Strickland III, A. J., Gamble, J. E., \& Peteraf, M. A. (2017). Crafting and Executing Strategy. The Quest For Competetive Advantage: Concepts.

[23] Yin, R. K. (2003). Application of Case Study Research Second Edition. In Interpretive Interactionism (2nd Editio). California: Sage Publication. 